\title{
Bet v 1- and Bet v 2-Associated Plant Food Sensitization in Uganda and Germany: Differences and Similarities
}

\author{
Leo Odongo $^{\mathrm{a}, \mathrm{b}}$ Grace Mulyowa $^{\mathrm{a}}$ Matthias Goebeler $^{\mathrm{b}}$ Axel Trautmann ${ }^{\mathrm{b}}$ \\ a Department of Dermatology, University Hospital Mbarara, Mbarara, Uganda; ${ }^{b}$ Department of Dermatology, \\ Venereology and Allergology, University Hospital Würzburg, Würzburg, Germany
}

\section{Key Words}

Africa · Alder pollen · Atopy · Birch pollen · Food allergy ·

Pollen allergy

\begin{abstract}
Background: Birch pollen allergy and concomitant plant food sensitization are well documented in Europe. However, there are currently no data available on pollen-associated plant food sensitization or even pollen allergy in tropical Africa. Our study aimed to investigate Bet v 1 - and Bet v 2-associated plant food sensitization in atopic patients from Uganda and compare it with sensitization rates in German patients. Methods: Sera from 83 Ugandan and 97 German atopic patients were analysed using UniCAP100' ${ }^{\mathrm{TM}}$ for allergen-specific IgE against the birch tree pollen allergens Bet $v$ 1 and Bet $v 2$ as well as the plant foods hazelnut, apple, kiwi, pea, peach, cherry, litchi, peanut, and soy. Results: As expected, sensitization to Bet $v 1$ and cross-reactive plant food allergens was more common in German atopic patients. In contrast, the prevalence of sensitization against Bet $v 2$ was remarkably similar in Ugandan and German patients. Interestingly, in Ugandan patients we found IgE-mediated sensitization against plant foods such as hazelnut, pea, peach, cherry, and litchi that are neither cultivated nor consumed in Uganda. Conclusions: For Ugandan atopic patients, sensiti-
\end{abstract}

(c) 2015 S. Karger AG, Base

$1018-2438 / 15 / 1674-0264 \$ 39.50 / 0$ zation against the Bet $v 2$ allergen (a plant profilin) may explain cross-reactivity to several plant foods which are not consumed in Uganda. Additionally, it is probable that sensitization of Ugandan atopics to alder pollen (Alnus acuminata, plant family Betulaceae) caused serological cross-reactivity with Betula verrucosa-related allergens.

(c) 2015 S. Karger AG, Basel

\section{Introduction}

The global prevalence of allergic diseases is reported to be in a range of $20-30 \%$ of the world's population [1]. In Europe, epidemiological studies have shown an increasing prevalence of IgE-mediated allergy and nowadays up to $25 \%$ of the European population suffer from some form of atopic diseases [2, 3]. In Africa the prevalence of atopic dermatitis, asthma and allergic rhinitis has also been increasing over the past decades [4]. Whereas birch pollen allergy and concomitant plant food sensitization is well documented in Europe, there are currently no published data about species-specific pollen allergy or associated plant food sensitization in tropical Africa.

Birch pollen allergy is one of the most frequent triggers of respiratory allergy diseases in European patients [5]. About $70 \%$ of these patients show IgE-mediated sensiti-
Correspondence to: Dr. Axel Trautmann

Department of Dermatology, Venereology and Allergology

University Hospital Würzburg

DE-97080 Würzburg (Germany)

E-Mail trautmann_a@ukw.de 
zation to plant foods such as hazelnut, apple, kiwi, carrot, or soy due to cross-reactivity between the major birch pollen allergen Bet $\mathrm{v} 1$ and homologous plant food allergens $[6,7]$ such as Cor a 1 [8], Mal d 1 [9], Pru p 1 [10], Api g $1[7,11,12]$, and Gly $m 4$ [13]. Typically, the mild clinical symptoms termed oral allergy syndrome are limited to the oral cavity [14].

Bet $\mathrm{v} 1$ is expressed in pollens of taxonomically related trees within the Betulaceae plant family. It belongs to the group I pathogenesis-related proteins, which are engaged in the defence of plants against microbial attack [15]. Bet $\mathrm{v} 2$ belongs to the profilin protein family (Bet $\mathrm{v} 2$ family), which are considerably conserved molecules with a high degree of structural homology between various plant species $[16,17]$. Due to its capacity to bind to actin, Bet v 2 participates in the regulation of plant cell division, growth and differentiation [17].

Our study investigated and compared IgE-mediated sensitization between Ugandan and German atopic patients against the recombinant birch pollen allergens Bet $\mathrm{v} 1$ and Bet $\mathrm{v} 2$ as well as potentially cross-reactive plant food allergens.

\section{Patients and Methods}

\section{Patients}

Ugandan patients attending the Dermatology Department at Mbarara University Hospital during the year 2013 were prospectively selected for this study when they fulfilled at least two of the following criteria: positive family history of atopy and a diagnosis of allergic rhinitis, allergic asthma and atopic dermatitis. Pregnant women and children below the age of 3 years were not evaluated. The study was approved by the Ethics Committee of the University Hospital Mbarara (project No. 09/03-13) and all patients gave informed consent. Data on German atopic patients were retrospectively retrieved from patient files within the time period from 2007 to 2010 of the Allergy Centre at the University Hospital Würzburg when they fulfilled the same criteria as the Ugandan patients. With regard to German patients, at that time IgE screening for birch pollen allergy and pollen-associated plant food sensitization was done as part of routine diagnostic practice and further ethical approval was therefore not required.

\section{IgE Measurement}

Venous blood samples of the Ugandan patients were obtained at the time of initial evaluation and sera were stored frozen at $-20^{\circ} \mathrm{C}$ until analysis. Ugandan and German serum samples were all analysed in Germany using the same UniCAP $100^{\mathrm{TM}} \operatorname{IgE}$ platform according to the procedure described by the manufacturer (Thermo Fischer Scientific; www.phadia.com). The sera were analysed for allergen-specific IgE against hazelnut (Thermo Fischer Scientific code f17), apple (f49), kiwi (f84), pea (f94), peach (f95), cherry (f242), litchi (f348), peanut (f352), and soy (f353) and for the recombinant birch tree pollen allergens rBet $\mathrm{v} 1$ ( $\mathrm{t} 215)$ and $\mathrm{rBet}$
Table 1. Clinical data of the Ugandan and German patients

\begin{tabular}{lcl}
\hline & $\begin{array}{c}\text { Uganda } \\
(\mathrm{n}=83)\end{array}$ & $\begin{array}{l}\text { Germany } \\
(\mathrm{n}=97)\end{array}$ \\
\hline $\begin{array}{l}\text { Age, years } \\
\quad \text { Mean }\end{array}$ & 29.8 & 39.1 \\
$\quad$ Range & $3-96$ & $14-78$ \\
Male/female & $27 / 56$ & $27 / 70$ \\
Atopy characteristics, $\mathrm{n}(\%)$ & & \\
$\quad$ Family atopy history & $41(49)$ & $52(54)$ \\
Allergic (seasonal) rhinitis & $54(65)$ & $67(69)$ \\
Allergic (seasonal) asthma & $9(11)$ & $41(42)$ \\
Atopic dermatitis & $2(2)$ & $8(8)$ \\
Total serum IgE, n & & \\
Not done & 2 & 60 \\
$<100 \mathrm{kU} / \mathrm{l}$ & 5 & 14 \\
$101-500 \mathrm{kU} / \mathrm{l}$ & 20 & 3 \\
$501-1,000 \mathrm{kU} / \mathrm{l}$ & 22 & 5 \\
$1,001-5,000 \mathrm{kU} / \mathrm{l}$ & 30 & 1 \\
$>5,000 \mathrm{kU} / \mathrm{l}$ & 4 & \\
\hline
\end{tabular}

$\mathrm{v} 2$ (t216). In clinical practice $0.35 \mathrm{kU} / \mathrm{l}$ is used as the cut-off value for positivity of allergen-specific IgE. However, quantitative measuring of IgE ranges from 0.1 to $100 \mathrm{kU} / \mathrm{l}$. Therefore, for improved sensitivity of the assay we, as well as other groups, used $0.1 \mathrm{kU} / \mathrm{l}$ as the detection threshold for allergen-specific IgE.

\section{Results}

\section{Patients}

A total of 83 Ugandan and 97 German atopic patients aged 3-96 years were evaluated. Patients recruited in Uganda were younger than the Germans and showed higher total serum IgE values (table 1). In this context it has to be considered that, unfortunately, in the majority of German patients no total serum IgE values were available retrospectively. Both the Ugandan and German atopic patient groups contained more females than males. With the exception of allergic rhinitis, the prevalence of allergic asthma and atopic dermatitis was higher in the German cohort.

\section{Bet $v 1$ and Bet $v 2$ Sensitization}

The difference in the serum concentrations of $\operatorname{IgE}$ antibodies against Bet $\mathrm{v} 1$ and Bet $\mathrm{v} 2$, expressed as the classical IgE CAP ${ }^{\mathrm{TM}}$ classes, is shown in table 2. Compared with the allergen-specific IgE values of German atopic patients Bet v-specific IgE values of Ugandans generally fell within lower classes. As expected, the prevalence of Bet $\mathrm{v} 1$ sensitization was higher in German atopic patients 
Table 2. Prevalence of IgE-mediated sensitization against rBet v 1 and rBet $\mathrm{v} 2$ in Ugandan and German atopic patients

\begin{tabular}{ccc}
\hline Betula verrucosa allergens & $\begin{array}{c}\text { Uganda } \\
(\mathrm{n}=83)\end{array}$ & $\begin{array}{c}\text { Germany } \\
(\mathrm{n}=97)\end{array}$ \\
\hline rBet v $1(\geq 0.1 \mathrm{kU} / \mathrm{l})$ & $22(26 \%)$ & $68(70 \%)$ \\
$0.10-0.35 \mathrm{kU} / 1$ & 19 & 3 \\
$0.36-0.70 \mathrm{kU} / 1$ & 2 & 3 \\
$0.71-3.50 \mathrm{kU} / 1$ & 1 & 11 \\
$3.50-17.50 \mathrm{kU} / 1$ & 0 & 15 \\
$17.51-50.00 \mathrm{kU} / 1$ & 0 & 23 \\
$50.01-100.00 \mathrm{kU} / 1$ & 0 & 8 \\
$>100.00 \mathrm{kU} / 1$ & 0 & 5 \\
$\mathrm{rBet} \mathrm{v} 2(\geq 0.1 \mathrm{kU} / \mathrm{l})$ & $22(26 \%)$ & $23(24 \%)$ \\
$0.10-0.35 \mathrm{kU} / 1$ & 17 & 3 \\
$0.36-0.70 \mathrm{kU} / 1$ & 1 & 4 \\
$0.71-3.50 \mathrm{kU} / 1$ & 3 & 13 \\
$3.50-17.50 \mathrm{kU} / 1$ & 1 & 3 \\
$17.51-50.00 \mathrm{kU} / 1$ & 0 & 0 \\
$50.01-100.00 \mathrm{kU} / 1$ & 0 & 0 \\
$>100.00 \mathrm{kU} / 1$ & 0 &
\end{tabular}

(70\%) compared with Ugandans (26\%). Using the detection threshold of $0.1 \mathrm{kU} / \mathrm{l}$, the prevalence of sensitization against Bet $\mathrm{v} 2$ was quite similar in the Ugandan and German patients (Uganda 26\%, Germany 24\%). Our study showed again that the prevalence of atopy and allergenspecific IgE sensitization generally decreases with increasing age (table 3 ).

\section{Sensitization against Specific Plant Food Allergens}

The prevalence of sensitization to specific plant food allergens was generally lower among Ugandan atopic patients compared with the Germans (table 4). Surprisingly, we found IgE-mediated sensitization of $\geq 0.1 \mathrm{kU} / \mathrm{l}$ in Ugandan atopic patients to plant food allergens that are neither consumed nor cultivated in Uganda, namely hazelnut (Uganda 54\%, Germany 71\%), pea (Uganda 33\%, Germany 69\%), peach (Uganda 53\%, Germany 73\%), cherry (Uganda 63\%, Germany 78\%), and litchi (Uganda $51 \%$, Germany 56\%). Sensitization of Ugandans against these plant food allergens was also detected in a significant number of patients when a detection threshold of $>0.35 \mathrm{kU} / \mathrm{l}$ was evaluated (table 4 ). On the other hand, in Ugandan patients the prevalence of sensitization to peanut $(20 \%$ with $\geq 0.1 \mathrm{kU} / \mathrm{l}$ and $2 \%$ with $>0.35 \mathrm{kU} / \mathrm{l})$ and soy ( $17 \%$ with $\geq 0.1 \mathrm{kU} / \mathrm{l}$ and $4 \%$ with $>0.35 \mathrm{kU} / \mathrm{l})$, which are commonly eaten in Uganda, was lower compared with the values concerning plant food allergens which are definitively not eaten in Uganda. Because two of the authors
Table 3. Age distribution (years) of Ugandan and German atopic patients with allergen-specific IgE against rBet v 1 and rBet v 2

\begin{tabular}{|c|c|c|c|c|c|}
\hline \multirow[b]{2}{*}{ Patients } & \multicolumn{5}{|c|}{ Age distribution } \\
\hline & $0-19$ & $20-39$ & $40-59$ & $60-79$ & $\geq 80$ \\
\hline \multicolumn{6}{|l|}{ Ugandan atopics } \\
\hline All $(\mathrm{n}=83)$ & 29 & 33 & 16 & 2 & 3 \\
\hline rBet v 1 IgE positive $(n=22)$ & 10 & 8 & 4 & 0 & 0 \\
\hline rBet v 2 IgE positive $(n=22)$ & 11 & 5 & 5 & 1 & 0 \\
\hline \multicolumn{6}{|l|}{ German atopics } \\
\hline All $(n=97)$ & 10 & 43 & 33 & 11 & 0 \\
\hline rBet v 1 IgE positive $(n=68)$ & 6 & 31 & 24 & 7 & 0 \\
\hline rBet v 2 IgE positive $(n=23)$ & 3 & 13 & 5 & 2 & 0 \\
\hline
\end{tabular}

(L.O. and G.M.) are inhabitants of South-Western Ugan$\mathrm{da}$, we had first-hand information about the consumption and cultivation of plant foods within this African region.

\section{Discussion}

Although birch trees are not domestic in Uganda, our study demonstrated specific IgE sensitization to Bet v 1 and Bet $\mathrm{v} 2$ not only in German but also in Ugandan atopic patients. Moreover, Ugandans showed sensitization to plant food allergens which are neither consumed nor cultivated in Uganda, namely hazelnut, pea, peach, cherry, and litchi. There may be two possible explanations for this observation.

First, in German atopic patients, sensitization against the major birch pollen allergen Bet $\mathrm{v} 1$ caused the wellknown Bet v 1-related cross-reactivity with several plant food allergens, as shown in table 5 [18]. For Ugandan atopic patients we hypothesize that sensitization to the profilin Bet $\mathrm{v} 2$, perhaps by pollen of different plant species, may be responsible for serological cross-reactivity to plant foods which are not eaten in Uganda. African finger millet (Eleusine coracana) is a major food crop in Uganda and belongs to the botanical Gramineae family [19]. Sensitization against pollen of, for example, this grass may be responsible for profilin-associated plant food sensitization.

Second, we speculate that a related plant of the same botanical family as the birch tree (Betulaceae) caused IgE cross-reactivity with Betula verrucosa allergens. Alnus acuminata (commonly called alder), which belongs to the Betulaceae family, is native in Argentina, Bolivia, Colombia, Central America, Mexico, and Peru [20,21]. In South- 
Table 4. Prevalence of plant food allergen-specific IgE values ( $\geq 0.1$ and $>0.35 \mathrm{kU} / \mathrm{l})$ in German and Ugandan atopic patients

\begin{tabular}{|c|c|c|c|c|c|}
\hline \multirow[t]{2}{*}{ Popular name } & \multirow[t]{2}{*}{ Botanical name } & \multicolumn{2}{|c|}{ Uganda $(\mathrm{n}=83)$} & \multicolumn{2}{|c|}{ Germany $(\mathrm{n}=97)$} \\
\hline & & $\geq 0.1 \mathrm{kU} / 1$ & $>0.35 \mathrm{kU} / \mathrm{l}$ & $\geq 0.1 \mathrm{kU} / 1$ & $>0.35 \mathrm{kU} / 1$ \\
\hline Hazelnut & Corylus avellana & 45 & 27 & 69 & 64 \\
\hline Apple & Malus domestica & 43 & 25 & 66 & 45 \\
\hline Kiwi & Actinidia deliciosa & 48 & 20 & 48 & 31 \\
\hline Pea & Pyrus communis & 27 & 26 & 67 & 54 \\
\hline Peach & Prunus persica & 44 & 25 & 71 & 57 \\
\hline Cherry & Prunus avium & 52 & 29 & 76 & 54 \\
\hline Litchi & Litchi chinensis & 42 & 31 & 54 & 26 \\
\hline Peanut & Arachis hypogaea & 17 & 2 & 67 & 61 \\
\hline Soy & Glycine maxima & 14 & 3 & 63 & 56 \\
\hline
\end{tabular}

Table 5. Bet v 1- and Bet v 2-related allergens in specific plant foods

\begin{tabular}{llll}
\hline Plant food & Botanical name & $\begin{array}{l}\text { Bet v 1-related } \\
\text { allergen }\end{array}$ & $\begin{array}{l}\text { Bet v 2-related } \\
\text { allergen }\end{array}$ \\
\hline Hazelnut & Corylus avellana & Cor a 1 & Cor a 2 \\
Apple & Malus domestica & Mal d 1 & Mal d 4 \\
Kiwi & Actinidia deliciosa & Act d 8 & Act d 9 \\
Pea & Pyrus communis & Pyr c 1 & Pyr c 4 \\
Peach & Prunus persica & Pru p 1 & Pru p 4 \\
Cherry & Prunus avium & Pru av 1 & Pru av 4 \\
Litchi & Litchi chinensis & n.d. & Lit c 1 \\
Peanut & Arachis hypogaea & Ara h 8 & Ara h 5 \\
Soy & Glycine maxima & Gly m 4 & Gly m 3 \\
\hline
\end{tabular}

n.d. = Not yet determined .

Western Uganda, a study was carried out to examine the effect of the integration of $A$. acuminata on farms on crop yields [22]. Since the Ugandan atopic patients whose sera were analysed in our study were from South-Western Uganda, it is probable that sensitization to pollen of $A$. acuminata caused cross-reactivity with $B$. verrucosa allergens.

We expected to find a higher prevalence of sensitization against peanut and soy in Ugandan atopic patients since both are commonly consumed and cultivated in Uganda. Surprisingly, our results showed a lower prevalence of sensitization against these foods (peanut $20 \%$ with $\geq 0.1 \mathrm{kU} / \mathrm{l}$ and $2 \%$ with $>0.35 \mathrm{kU} / \mathrm{l}$, soy $17 \%$ with $\geq 0.1 \mathrm{kU} / \mathrm{l}$ and $4 \%$ with $>0.35 \mathrm{kU} / \mathrm{l}$ ) compared with foods not eaten there such as, for example, hazelnut ( $54 \%$ with $\geq 0.1 \mathrm{kU} / \mathrm{l}$ and $32 \%$ with $>0.35 \mathrm{kU} / \mathrm{l})$ or cherry $(63 \%$ with $\geq 0.1 \mathrm{kU} / \mathrm{l}$ and $35 \%$ with $>0.35 \mathrm{kU} / \mathrm{l})$. It is tempting to speculate that these results support the hypothesis that regular oral exposure may play a role in the suppression of IgE-mediated food sensitization by triggering gastrointestinal immune tolerance mechanisms [23].

To the best of our knowledge, the present study is the first to compare serological Bet $\mathrm{v} 1$ and Bet $\mathrm{v} 2$ reactivity in patients from two countries on different continents. Germany enjoys a moderate climate within Europe characterized by moderate annual temperature fluctuations, whereas Uganda in tropical Africa has a tropical climate all year long. We demonstrated Bet v 1 reactivity in $70 \%$ of German atopic patients and in only $26 \%$ of the Ugandans. Unexpectedly, we found a striking similarity in the general prevalence of IgE sensitization $(\geq 0.1 \mathrm{kU} / \mathrm{l})$ to Bet v 2 among Ugandan (26\%) and German (24\%) atopic patients. Previous studies showed regional variations within specific IgE profiles among birch pollen-sensitive European individuals. Moverare et al. [24] examined 242 patients with seasonal rhinitis and/or asthma from Finland, Sweden, Austria, France, Switzerland, and Italy. Finnish, Swedish and Austrian sera contained the highest percentage of IgE positivity for Bet v 1 ( $\geq 98 \%)$. Bet v 1 -specific IgE was found in $90 \%$ of the French sera and in 65 and $62 \%$ of the sera from Switzerland and Italy, respectively. Only $2 \%$ of the Finnish and $12 \%$ of the Swedish patients had IgE positivity to Bet $\mathrm{v} 2$, while Bet $\mathrm{v} 2$ reactivity was more common in the other populations (20-43\%).

Our study showed that the prevalence of allergen-specific IgE sensitization decreases with increasing age of the patients. This finding is in agreement with results of several other studies. Sekerkova and Polackova [3] stated that the prevalence of Bet v 1-, Bet v 2- and Bet v 4-spe- 
cific IgE in birch pollen-allergic individuals is dependent not only on the region in which they live but also on their age. Mediaty and Neuber [25] found that total and allergen-specific serum IgE decreases with age in patients with allergic rhinitis and asthma but not in patients with atopic dermatitis. Within the framework of the SAPALDIA survey (Swiss Study on Air Pollution and Lung Diseases in Adults), it was also shown that atopy prevalence decreases with increasing age [26]. However, rates of $\operatorname{IgE}$ sensitization are on the increase worldwide and therefore it is not surprising that the prevalence of atopy and allergen-specific IgE sensitization generally decreases with increasing age.

In the interpretation of our data, the detection threshold of allergen-specific IgE of $0.1 \mathrm{kU} / \mathrm{l}$ is an important issue. Principally, the ImmunoCAP method can quantitatively detect allergen-specific IgE down to a threshold of $0.1 \mathrm{kU} / 1$ [27]. In comparison with the conventional 0.35 $\mathrm{kU} / \mathrm{l}$, a cut-off value of $0.1 \mathrm{kU} / \mathrm{l}$ increases the sensitivity of allergen-specific IgE measurement. Importantly, the cut-off value of $0.1 \mathrm{kU} / \mathrm{l}$ is obviously not accompanied by a decreased specificity of the assay, as shown, for example, by the small numbers of German patients with rBet v 1- and $\mathrm{rBet} v 2$-specfic IgE values between 0.1 and $0.35 \mathrm{kU} / \mathrm{l}$. Moreover, the rather unexpected sensitization of Ugandans against certain plant food allergens was also detected when a cut-off value of $>0.35 \mathrm{kU} / \mathrm{l}$ was evaluated (table 4 ).

We found that the prevalence of asthma and atopic dermatitis was higher in German atopic patients than in Ugandan atopics. This is in line with observations from the ISAAC study (International Study of Asthma and Allergies in Childhood) showing that there was clearly a lower prevalence of allergic diseases in developing countries [28]. The predominantly rural settlement of patients living in South-Western Uganda appears to be protective against the development of certain atopy diseases, supporting the hygiene hypothesis by which early exposure to environmental allergens and infectious agents leads to the development of immunological tolerance [29].

\section{Acknowledgements}

L.O. was supported by an educational grant from the German Academic Exchange Service (Deutscher Akademischer Austauschdienst, DAAD). We thank Prof. Dr. Gerold Jäger for valuable advice and Sigrid Lempert for excellent technical assistance.

\section{References}

-1 Pawankar R, Baena-Cagnani CE, Bousquet J, Walter Canonica G, Cruz AA, Kaliner MA, Lanier BQ: State of World Allergy Report 2008: allergy and chronic respiratory diseases. World Allergy Org J 2008;1:4-17.

- 2 Simpson CR, Newton J, Hippisley-Cox J, Sheikh A: Incidence and prevalence of multiple allergic disorders recorded in a national primary care database. J R Soc Med 2008;101: 558-563.

-3 Sekerkova A, Polackova M: Detection of Bet v 1 , Bet $\mathrm{v} 2$ and Bet $\mathrm{v} 4$ specific IgE antibodies in the sera of children and adult patients allergic to birch pollen: evaluation of different IgE reactivity profiles depending on age and local sensitization. Int Arch Allergy Immunol 2011;154:278-285.

-4 Zar HJ, Ehrlich RI, Workman L, Weinberg EG: The changing prevalence of asthma, allergic rhinitis, and atopic eczema in African adolescents from 1995 to 2002. Pediatr Allergy Immunol 2007;18:560-565.

5 Caillaud D, Martin S, Segala C, Besancenot JP, Clot B, Thibaudon M: Effects of airborne birch pollen levels on clinical symptoms of seasonal allergic rhinoconjunctivitis. Int Arch Allergy Immunol 2014;163:43-50.
6 Kazemi-Shirazi L, Pauli G, Purohit A, Spitzauer S, Fröschl R, Hoffmann-Sommergruber $\mathrm{K}$, Breiteneder $\mathrm{H}$, Scheiner O, Kraft D, Valenta R: Quantitative IgE inhibition experiments with purified recombinant allergens indicate pollen-derived allergens as the sensitizing agents responsible for many forms of plant food allergy. J Allergy Clin Immunol 2000;105:116-125.

7 Bohle B, Radakovics A, Jahn-Schmid B, Hoffmann-Sommergruber K, Fischer GF, Ebner $\mathrm{C}$ : Bet $\mathrm{v} 1$, the major birch pollen allergen, initiates sensitization to Api g 1, the major allergen in celery: evidence at the T cell level. Eur J Immunol 2003;33:3303-3310.

8 Le TM, van Hoffen E, Lebens AFM, Bruijnzeel-Koomen CAFM, Knulst AC: Anaphylactic versus mild reactions to hazelnut and apple in a birch-endemic area: different sensitization profiles? Int Arch Allergy Immunol 2013; 160:56-62.

-9 Vanek-Krebitz M, Hoffmann-Sommergruber K, Laimer da Camara Machado M, Susani M, Ebner C, Kraft D, Scheiner O, Breiteneder $\mathrm{H}$ : Cloning and sequencing of Mal d 1, the major allergen from apple (Malus domestica), and its immunological relationship to Bet v 1, the major birch pollen allergen. Biochem Biophys Res Commun 1995;214:538551 .
10 Gaier S, Marsh J, Oberhuber C, Rigby NM Lovegrove A, Alessandri S, Briza P, Radauer C, Zuidmeer L, van Ree R, Hemmer W, Sancho AI, Mills C, Hoffmann-Sommergruber K, Shewry PR: Purification and structural stability of the peach allergens Pru p 1 and Pru p 3. Mol Nutr Food Res 2008;52:220-229.

-11 Breiteneder H, Hoffmann-Sommergruber K, O’Riordain G, Susani M, Ahorn H, Ebner C, Kraft D, Scheiner O: Molecular characterization of Api g 1, the major allergen of celery (Apium graveolens), and its immunological and structural relationships to a group of 17 $\mathrm{kDa}$ tree pollen allergens. Eur J Biochem 1995; 233:484-489.

12 Hoffmann-Sommergruber K, Ferris R, Pec M, Radauer C, O’Riordain G, Laimer Da Camara Machado M, Scheiner O, Breiteneder $\mathrm{H}$ : Characterization of Api g 1.0201, a new member of the Api $\mathrm{g} 1$ family of celery allergens. Int Arch Allergy Immunol 2000;122:115-123.

-13 Berneder M, Bublin M, Hoffmann-Sommergruber K, Hawranek T, Lang R: Allergen chip diagnosis for soy-allergic patients: Gly $\mathrm{m} 4$ as a marker for severe food-allergic reactions. Int Arch Allergy Immunol 2013;161:229-233.

$>14$ Vieths S, Scheurer S, Ballmer-Weber B: Current understanding of cross-reactivity of food allergens and pollen. Ann NY Acad Sci 2002; 964:47-68. 
15 Gajhede M, Osmark P, Poulsen FM, Ipsen H, Larsen JN, Joost van Neerven RJ, Schou C, Løwenstein H, Spangfort MD: X-ray and NMR structure of Bet $v 1$, the origin of birch pollen allergy. Nat Struct Biol 1996;3:10401045.

16 Fernandez Rivas M: Cross-reactivity between fruit and vegetables. Allergol Immunopathol 2003;31:141-146.

17 Valenta R, Ferreira F, Grote M: Identification of profilin as an actin-binding protein in higher plants. J Biol Chem 1993;268:2277722781.

18 http://www.allergome.org (accessed February 6,2015$)$.

19 http://www.arsgrin.gov/npgs/aboutgrin (accessed February 6, 2015).

20 Hokche O, Berry PE, Huber O (eds): Nuevo Catálogo de la Flora Vascular de Venezuela. Caracas, Fundación Instituto Botánico de Venezuela, 2008, pp 1-859.
21 Berendsohn WG, Gruber AK, MonterrosaSalomon JA: Nova silva cuscatlanica. Arboles nativos e introducidos de El Salvador. Parte 1. Angiospermae - Familias A a L. Englera 2009; 29:1-448.

22 Siriri D, Ong CK, Wilson J, Boffa JM, Black CR: Tree species and pruning regime affect crop yield on bench terraces in SW Uganda. Agroforestry Syst 2010;78:65-77.

23 Worbs T, Bode U, Yan S, Hoffmann MW, Hintzen G, Bernhardt G, Forster R, Pabst O: Oral tolerance originates in the intestinal immune system and relies on antigen carriage by dendritic cells. J Exp Med 2006;203:519-527.

24 Moverare R, Westritschnig K, Svensson M, Hayek B, Bende M, Pauli G: Different IgE reactivity profiles in birch pollen-sensitive patients from six European populations revealed by recombinant allergens: an imprint of local sensitization. Int Arch Allergy Immunol 2002;128:325-335.

25 Mediaty A, Neuber K: Total and specific serum IgE decreases with age in patients with allergic rhinitis, asthma, and insect allergy but not in patients with atopic dermatitis. Immun Ageing 2005;2:9.
26 Wüthrich B, Schindler C, Medici TC, Zellweger JP, Leuenberger P: IgE levels, atopy markers and hay fever in relation to age, sex and smoking status in a normal adult Swiss population. SAPALDIA (Swiss Study on Air Pollution and Lung Diseases in Adults) Team. Int Arch Allergy Immunol 1996;111:396-402.

27 Johansson SG: ImmunoCAP ${ }^{\mathrm{TM}}$ specific IgE test: an objective tool for research and routine allergy diagnosis. Expert Rev Mol Diagn 2004; 4:273-279.

28 The International Study of Asthma and Allergies in Childhood (ISAAC) Steering Committee: Worldwide variation in prevalence of symptoms of asthma, allergic rhinoconjunctivitis and atopic eczema. Lancet 1998;351: 1225-1232.

29 Schram ME, Tedja AM, Spijker R, Bos JD, Williams HC, Spuls PI: Is there a rural/urban gradient in the prevalence of eczema? A systematic review. Br J Dermatol 2010;162:964973. 